\title{
İş Bölümünün Evrimi: Antik Çağdan Klasik Yönetim Düşüncesine Bir İnceleme*
}

\author{
Duygu TOPLU YAŞLIOĞLUU*, Murat YAŞLIOĞLU ${ }^{* * *}$
}

\section{$\ddot{0} \mathbf{z}$}

Bu çalışmada "bir işin iki ya da daha fazla bireye dağıtılarak, bir iş bileșenleri serisi haline getirilmesi" olarak tanımlanan işbölümü kavramı anlamından ve kullanımından ziyade evrimsel süreci içerisinde incelenmektedir. İş bölümü kavramı antik çağlardan başlayarak klasik yönetim düşüncesine kadar çeşitli alanlar dâhilinde incelenmiş ve yorumlanmıştır. İş bölümünün sadece teknik işlerde değil, zihinsel süreçlerde de ele alınması gerektiği savunulmaktadır. Bu bakış açısı klasik yönetim düşüncesindeki işbölümü kavramı ile değerlendirilmiş, klasik yönetim düşünürlerinden Fayol'un ortaya attığı yönetim ilkelerinin yönetsel işbölümü çerçevesinde şekillenmesine yol açmıştır. Bu çalışmada söz konusu olan yönetsel işbölümü Fayol'un işbölümü ilkesi hariç diğer 13 yönetim ilkesinin sinıflandırılması ile oluşturulmuştur. Bu doğrultuda, işbölümü kavramının tarihsel incelemesi yaplarak işletme yönetimi açısından öneminin vurgulanması, kavramın birçok düşünce ve akımın çıkış noktası olduğunun anlaşılması açısından önem taşımaktadır.

Anahtar Kelimeler: İş Bölümü, Uzmanlaşma, Klasik Yönetim Teorisi, Yönetsel Teori, Neoklasik Teori.

\section{Evaluation of Division of Labor: An Investigation from Archaic Times to Classical Management Thought}

\begin{abstract}
Concept of division of labor defined as "distributing a job into two or more individuals, making it a series of business components" is examined in its evolutionary process rather than its meaning and usage. The concept of division of labor has been examined and interpreted in various fields from the antique ages to the classical management thought. The division of labor should be adressed not only in technical affairs, but also in cognitive processes. This point of view has been evaluated with the concept of division of labor in classical management thought, and it has led to the shaping

Derleme Makale (Review Article)

Geliş/Received: 13.12 .2018

Kabul/Accepted: 21.05 .2020

DOI: https://dx.doi.org/10.17336/igusbd.495809

* Bu çalışma, 9 Nisan 2018 tarihinde gerçekleşmiş olan İşletme ve Yönetim Tarihi Konferansı'nda özet olarak sunulmuștur.

${ }^{* *}$ Dr., İstanbul Üniversitesi, İşletme Fakültesi, İşletme Yönetimi ve Organizasyon Anabilim Dall, İstanbul, Türkiye, E-posta: duygut@istanbul.edu.tr ORCID https://orcid.org/0000-0002-5637-8999 *** Doç. Dr., İstanbul Üniversitesi, İșletme Fakültesi, İşletme Yönetimi ve Organizasyon Anabilim Dalı, İstanbul, Türkiye, E-posta: muratyas@istanbul.edu.tr ORCID https://orcid.org/0000-0003-2464$\underline{5439}$
\end{abstract}


of the management principles introduced by Fayol in the framework of the managerial division of labor. This managerial division of labor is formed by the classification of 13 management principles. In this direction, it is important to emphasize the importance of the division of labor in terms of business management and to understand that the concept is the starting point of many thoughts.

Keywords: Division of Labor, Specialization, Classical Management Thought, Managerial Theory, Neoclassical Theory.

\section{Giriş}

İnsanlığın bilinen tarihinden buyana yönetim ve organizasyon kavramları şekillenmektedir; kimi zaman daha baskın kimi zaman da ahlaka ve insan doğasına ters düşmesi nedeniyle daha çekinik olarak işbölümü ve uzmanlaşma üzerinde durulmuştur. İș bölümü ve uzmanlaşma kavramlarını birbirlerinden ayırmak neredeyse imkânsızdır. Uzmanlaşma işbölümünün bir sonucudur; işbölümü ile istenen sonuç da kesin bir uzmanlașma ve standartlaşmadır. Tanımında ve etkileri üzerinde anlamsal bir değișme olmamasına rağmen zaman içinde işbölümü ve uzmanlaşmaya verilen önemi yönetim tarihiyle birlikte incelemek doğru olacaktır. İnsanlık tarihi kadar eski bir kavram olan işbölümü, insanın varoluşu ile birlikte nüfusun artması ve insanlar arasındaki dayanıșma dolayısıyla iş ölümü kendiliğinden ortaya çıkmıştır. İnsanın var olduğu günden itibaren kendiliğinden oluşan işbölümü kavramının 1776 yılında Adam Smith'in ve 1893'de Emile Durkheim'in yapmış olduğu bilimsel çalışmalarla kavram olarak ortaya konduğu iddia edilmektedir. İș bölümü kavramına ilişkin yapılmış birçok bilimsel çalışma, kavramı farklı açılardan irdelemiş olsa da üzerinde en çok durulan konu toplumsal işbölümü ve yönetimde işbölümüdür. Adam Smith bir iktisatçı olarak işbölümünü ilerlemenin başlıca etmeni olarak görmekte Durkheim ise toplumda işbölümü kavramı üzerinde durmakta ve her ikisi de işbölümünün insanların refah ve mutluluklarını arttırmak yönünde olumlu bir faydası olduğu konusunda hemfikir görüşler bildirmektedir. Klasik yönetim düşünürleri ise insanı bir makine olarak gören bir yaklaşım içerisinde işbölümü ve uzmanlaşmanın verimliliği arttırdığı üzerinde durmakta ancak işbölümüne teknik, yönetsel, bürokratik açılardan yaklaşmaktadır.

\section{Eski Çağlarda İş Bölümü}

Yönetim ve organizasyon kavramları insanların ortaya çıkışından itibaren süregelen bir kavramdır. Tüm uygarlıklar eserlerini ortaya koyarken örgütleme sürecinden ve yönetimden faydalanmışlardır. Tarihte işbölümünün en eski örneklerine Sümerlilerde rastlanmaktadır. Sümerlilerde ülkenin yönetiminden sorumlu insanlar olarak görülen rahipler tarafından her iş belirli gruplara verilirdi. Örneğin, tarımla uğraşan bir kişinin başka bir işle uğraşması tanrıların ona verdiği yeteneklere hakaret etmesi olarak düşünülür ve cezalandırılırdı, yine aynı şekilde rahiplerin görevleri de kontrol etmekti ve herhangi bir işe yardım etmeleri ruhani liderlikten çıkmalarına neden olur ve kirlenmiş sayılırlardı. İş bölümü ve uzmanlaşmanın en eski örneği olarak vurgulanan bu yapı beraberinde sınıf ayrılıklarını doğurmakta ve binlerce yıl sonra en çok tartışılacak olan konu olan sınıf ayrılıklarının temelini ve belki de Rönesans'ın ilk temellerini ortaya koymaktaydı. Sümerlilerden sonra işbölümünün örnekleri Mısırlılarda görülmektedir. Nil nehrinde sulama kanallarını kurarken marangozlar, mühendisler, kazıcılar, taşıyıcılar, montajcılar işbölümünden faydalanmışlardır. Günümüzde de halen ayakta duran ve mimarinin en eski örneklerinden bilinen piramitler yapılırken taşların kazılıp çıkarılması farklı kişilerce temizlenip yontulması ve daha farklı kişilerce ve 
taşınması, yerleştirilmesi, yerleşimin planlanması yapılmıştır. Tüm organizasyon için de yine bazı kişiler görevlendirilmiş, bir nevi ellerinde kâğıt ve kalemler ile işleri düzenlemişlerdir (Wren, 1972). Bugünkü yönetimin temelleri olarak sayılabilecek bu düzen yine işlerin parçalara bölünmesi ve bunların organizasyonu ile ortaya çıkmıştır.

Çin'i uzmanlaşmaya götüren sebep ise yoğun savaş baskısıdır. Orta Asya Türkleri ile olan savaşları onların askeri örgütlenmeyi çok sıkı tutmalarına neden olmuştur. Çin binlerce yıllık tarihinde gerek Türkler gerekse Moğollar tarafından ya da batıdan gelen tehditlerle sürekli baskı altında yaşamış bir toplumdur. MÖ. 500 yılında Sun Tzu tarafından yazılan "Savaş Sanatı" adlı eserde askeri açıdan uzmanlaşmanın ve işbölümünün hayati önemi üzerinde durulmuş ve bir askeri yapının kesin çizgilerle ayrılmış, çok ufak parçalara bölünmüş işbölümlerinden oluşması gerektiği ve her işbölümünde görevlendirilmiş askerin sadece kendi işini yapması gerektiği vurgulanmıștır (Hodgetts, 1997). Tzu, yaptığı iște çok iyi uzmanlaşan bir askerin yapacağı hata ihtimalinin neredeyse sıfır olduğunu iddia etmektedir. Bu işbölümü ve dolayısıyla uzmanlaşma durumu katı hiyerarşik yapı ile desteklenmeli ve kontrol, örgütleme fonksiyonları çok iyi yerine getirilmelidir (Wren, 1972). Günümüz askeri sistemleri de bu ișbölümü ve uzmanlaşma ve yine bunların doğurduğu keskin hiyerarșik kademeler üzerinden işlemekte ve yürümektedir. Sun Tzu'nun bahsettiği yapı incelendiğinde Weber'in ortaya attığı bürokrasi modeline yakınlıkların mevcudiyeti göze çarpmaktadır.

18. yüzyılın ikinci yarısında meydana gelen "sanayi devrimi" ne kadar yönetim düşüncesi esas itibariyle filozofların işi olmuş, çalışma ve ticari faaliyetlerle, yönetim ve örgüt kavramlarına ilişkin fikir ve görüşlerinden oluşmuştur. MÖ 400 yılında Plato'nun işbölümü ile para ve pazar arasındaki ilişkiyi ortaya koymasıyla tanımlanan işbölümü kavramı Büyük İskender'in de sınırları okyanuslara dayanan ülkesinin idaresinde ve ordusunun bölümlendirilmesinde uzmanlaşmaya büyük önem vermesine yol açmıștır (Cheng, 2004).

MÖ 400 yılında Plato bilimsel yöntemlerin uygulanması ve çalışma ahenginin önemi üzerinde durmuş, işbölümü ile para ve pazar arasındaki ilişkiyi ortaya koymuştur (Nişancı, 2015). Onun görüşlerinden fazlasıyla etkilenen Büyük İskender de sınırları okyanuslara dayanan ülkesinin idaresinde ve ordusunun bölümlendirilmesinde uzmanlaşmaya büyük önem vermiştir. Büyük İskender hükümdarlığı altında (MÖ 350) görkemli örgütlere sahip olan bir devlet ortaya çıkmıştır (Cheng, 2004).

Eski Mezopotamya, Grek ve Roma medeniyetleri, politik işlerin yürütülmesinde, yolların ve binaların inşa edilmesinde, karmaşı muhasebe sistemlerinin geliştirilmesinde, idari uygulamalarda yönetim ilkeleri uygulamış ve başarılı sonuçlar elde etmiştir (Nişancl, 2015). Romalılar tarafından kurulan uygarlıkta da daha çok askeri yapıya önem veren Roma lejyonları için silah üreten yarı fabrika üretim sistemleri geliştirilmiş ve daha sonraları aynı sistemi ticari amaçla ürettikleri tekstil için de kullanmıșlardır. Büyüyen ihracat sistemi beraberinde standartlaşma zorunluluğunu getirmiștir. Ayrıca savaş ihtiyaçlarını karşılamak için tarihin ilk tüzel kişiliğe sahip işletmeleri ortaya çıkmıştır (Wren, 1972). Böyle bir sistem çok iyi uzmanlaşma ve işbölümünü beraberinde getirmekte; ustabaşı ve usta kavramına temel olan bu yapı daha sonraları feodal yapıda üretimin temeli, daha sonraları da yeniden yapılanmada işletmelerin farklılaşmasının temeli haline gelmiştir.

Roma Katolik kilisesi büyük Roma imparatorluğunun yıkılmasından sonra yönetimin merkezi haline gelmiş, eski yönetim düşüncesine önemli katkılarda bulunmuştur. Neredeyse tüm Avrupa'yı dini baskılar ile idare eden bu yapı kendi içindeki yönetimde önemli bir yapılanmaya gitmiștir. Kilisede, rahipler, papazlar ve diğer çalışanlar olarak meslek tanımlamalarının kullanılması, herkesin görevinin açık ve kesin olması, ruhani sınıfa mensup olmayanlardan, papaya kadar uzanan bölümlendirilmiş bir idare zinciri işbölümünün ne denli önemli olduğunu göstermektedir (Baransel, 1993). 
Roma'nın yıkılmasından sonra ortaya çıkan ekonomik, sosyal ve politik kaos feodal yapının oluşması için tam kıvamında bir zemin hazırlamış, Feodalizm toprağa dayalı kültürel ve ekonomik bir sistem olarak 600 yılından 1500 yılına kadar hüküm sürmüştür. İnsanların kendilerini tamamen tarıma adadıkları, toprak sahipliğine dayalı bu sistemde güçlü bir merkezi yapının olmayıșı, parçalanmış bir yönetim yapısının ortaya çıkmasına neden olmuştur (Zagolov, 1976). 1300-1500 yılları arasında savaş gemilerinin inşa edilmesi ve muhafaza edilmesi için inşa edilmiş olan Venedik Tersanesi'nde 1430 yıllarından itibaren tekne gövdeleri inşa edilmesi için kullanılan sistem işbölümünün önemli örneklerinden sayılmaktadır. Venedik Tersanesi yönetiminde aşırı uzmanlaşma, fabrika işçilerinde uzmanlaşmanın yoğun bir şekilde uygulanması, kontrol kavramı, verimliliğin hesaplanması söz konusudur. Venedik Tersanesi yönetim tarihinde uluslararası düzeyde önem taşımakla birlikte genellikle akademik çalışmalarda önemi göz ardı edilmektedir (Zan, 2004; Nişancı, 2015).

\section{Adam Smith ve Charles Babbage'ın İş Bölümü Üzerine Çalışmaları}

Adam Smith'in fikirleri 1760 ve öncesine ait fikirler olup kendisi kurulu düzene getirdiği birçok eleştiri ile ön plana çıkmıştır (Applegate, 2003). Serbest pazar ekonomisi, rekabetçi kapitalizm, yönetimin rolü ve fonksiyonu, üretkenliğin temelleri gibi konular Adam Smith'in "iğne fabrikası" araştırması ve iş bölümü teorisinden sonra tartışılmaya başlanmıştır. Smith etkililiğin temel kaynağı olan işbölümünü üç temelde incelemiştir (Chandra, 2004):

$>$ İşçinin hüneri,

> Görevden göreve geçişin olmaması sonucu kazanılan vakit,

$>$ Daha iyi teknikler, makineler ve yaratıcılık.

Smith'ten yaklaşık 50 yıl sonra Charles Babbage etkililiğe bir dördüncü maddeyi de ekleyerek Smith'in ilk başlardaki tartışmalarına atıfta bulunmuştur: maliyet düşürme. Smith bu konuya iş gücünün performansını arttırarak üretkenliğin arttırılabileceğini söyleyerek değinmiş olsa da Babbage, yönetimin bilimsel anlayışı üzerinde durmuş, işbölümü, zaman ve hareket etütleri, muhasebe uygulamaları üzerine çalışarak işbölümünün işgücü maliyetini nasıl azaltacağı ve karlılığı nasıl artıracağını hesaplamıştır (Dumville ve Torano, 1997). Babbage, yönetimin bilimsel anlayışı üzerinde durmuş, işbölümü, zaman ve hareket etütleri, muhasebe uygulamaları üzerine çalışmıștır. Smith'e göre işbölümü sınırsız değildir ve pazarın genişliği ile işletmenin büyüklüğüne bağlıdır. Örneğin, bir işletme günde bir ürün üretiyorsa bu iş için bir kişi yetecekken iş ikiye çıktığında iki, üçe çıktığında üç kişi gerekecektir. Fakat işi tüm olarak bir kişinin yapmasındansa ișbölümlerine ayrılırsa, bu kişiler yerine getirdikleri görevlerde uzman olacak ve işlerini en iyi, en hızlı şekilde yerlerine getireceklerdir. Sonuç olarak 500 parça iş için 500 kişi yerine sadece 5-10 kişi yetecektir (Dumville ve Torano, 1997).

İş bölümü ve uzmanlaşmanın pozitif etkileri ekonominin ve günümüzün en başta gelen varsayımlarından biridir. Olumlu etki ilk olarak Adam Smith'in "Ulusların Zenginliğiı"' adlı eserinde bulunan iğne fabrikası araştırmasında ve Charles Babbage'ın "Makineleşme ve Üretim Ekonomisi" (1832) adlı kitabında incelenmiştir. Fakat Andrew West varsayımlarla yapılan bu gözlemi bir adım öteye taşıyarak flüt fabrikası üzerinde ampirik bir çalışmada bulunmuştur (West, 1999). Adam Smith "Ulusların Zenginliği" adlı kitabında 18. yüzyıl iğne üretim fabrikasında bir araștırma ve gözlem yapmıștır, daha sonra Charles Babbage işbölümünün iğne üretim maliyetleri üzerindeki etkisini incelemiş ve araştırmayı bir adım öteye taşımıştır. Fakat varsayımlar üzerine kurulmuş bu araştırma ilk defa Andrew West tarafından araştırılmış ve ortaya konulmuştur. 
Adam Smith işbölümünü bir işin iki ya da daha fazla bireye dağıtılarak, bir iş bileşenleri serisi haline getirilmesi olarak tanımlamıștır. Bu tanım üzerinden iğne yapımını inceleyerek bileșenlerine ayırmıș, azami sayıda iğne üretimini gerçekleștirmeye uğraşmıştır (Greiner 1972; Smith, 2005). Babbage, Smith'in çalışmasını bir adım daha öteye taşımış ve çıktıyı artırmanın yanında yetenek ve güçten ekonomi sağlamayı da bașka bir deyișle maliyet ve karlılığı hesaba katmıștır (Babbage, 1832). Bununla birlikte Babbage, Smith'in araştırmasına; görevin gerektirdiği yetenek, görev başına ücret, görevin aldığı zaman ve işin toplam maliyeti kavramlarını da eklemiștir (West, 1999) Açıkça görülmektedir ki Smith ve Babbage'ın çalışmaları işbölümünü hem verimlilik hem de etkinlik açısından faydalarını sayısal olarak ortaya koymaktadır.

Adam Smith'in ișbölümü hakkındaki görüşleri yıllardır eleştirilmektedir. Smith “Ulusların Zenginliği”nin 1. kitabında işlerin bölümlendirilmesinin büyük faydalarından bahsederken, 5. ciltte işbölümünün yıkıcı etkenlerinden bahsetmektedir. Smith, ilk kitabında işlerin spesifik parçalara bölünmesi ile işçilerin bu işleri yaparken tüm dikkatlerini ve heveslerini bu işlere vereceğini, böylece zaten yaradılıșında olan işi en kolay ve en çabuk yapma yolunu üretme zekâsını kullanacağını iddia etmektedir. Yalnız daha sonraları değindiği nokta ise bu aşırı uzmanlaşmanın insanların yoğun ve hızlı gelişmelere uyum sağlamasını engellediğidir. Smith, işbölümünün ileri seviyelerinde işçilerin "aptal" ve "cahil" olmalarından ve sadece tek iși yapabilecek duruma gelmelerinin rutinliğinden bahsetmeye çalışırken, bu görüşleri onu eleștirilere maruz bırakmıştır. Tek bir işte uzmanlaşmış işçi ucuz ve faydalı işgücü yaratacaktır, bu da kapitalist görüşün iştahını kabartan bir etkendir (Pavitt, 1998; Rosenberg, 1965). Daha sonraları Marx da bu görüş üzerinde çalışmalar yapmıştır (Dumville ve Torano, 1997). Kimi Smith'in bu iki farklı görüşünü yetersiz ve çelişkili bulurken, kimi ise Smith'in iki uç noktayı betimlemek istediğini düşünmekte ve așırı uzmanlașmanın zararlarından bahsettiğini kabul etmektedir.

Toplumsal iș bölümü kavramını ortaya koyan düşünür Emile Durkheim, dikkatini iş bölümü üzerine yoğunlaştırarak çalışmalarında sınıf çelişkisi üzerinde durmamıştır. Ancak benzer bakış açısıyla sosyolojik araștırmalar yapan Marx ise iş bölümünü; üretim, emek ya da işin teknik bir çerçeve içerisinde bölümlenmesi durumunda ortaya çıan bir kavram olarak nitelendirmiş olup sınıf ve işbölümünün endüstri toplumunun bir gereği olduğunu öne sürmüştür. Marx, iş bölümü ile ilgili çalışmalarında makinaların kullanımı ve makine tipi üretimden büyük ölçekli sanayiye geçiş ile ilgili görüşlerde bulunmuş, emek bölümü üzerine tartışmıștır. Smith'in yaşamış olduğu görüş karmaşasını değerlendirerek mübadele ve piyasa değerleme teorileri üzerinden emek bölümü hakkında açılamalarda bulunarak, emek bölümünün toplumsal ve teknik emek bölümü olarak ayrıldığını öne sürmüştür (Narin, 2010; Marx, 1993).

\subsection{Charles Babbage ve "Zihinsel İş Bölümü"}

İngiliz matematikçi olan Charles Babbage'ın çalışmaları onu yönetimle bağdaşan şaşırtıcı sonuçlara yönlendirmiştir. Matematiksel işlemleri hızlandırmak üzere yaratmış olduğu "fark makinesi" bugünkü bilgisayarların temelini oluşturmaktadır. Babbage'ın fabrikalarda yapmış olduğu araştırmalar onu Smith'in yoluna sürüklemiş, Smith'in yapmış olduğu iğne fabrikası araștırmasını derinleștirmiş ve daha sonraları büyük değișikliklere neden olacak ilkelere ulaștırmıștır. Babbage'ın ortaya koyduğu yöntemler ve sonuçlar Frederick W. Taylor'un da görüşlerine ve kendisinden sonra yeșerecek olan klasik yönetim düşüncesine temel ders teşkil etmiştir (Merrill, 1970). Frederick Taylor ve Henri Fayol, Smith ve Babbage'ın ortaya koyduğu işbölümü ve uzmanlaşma temeline dayanarak bilimsel yönetimin yöntemini bu görüşler üzerine kurmuşlardır (Wren, 1972). 
Babbage'a göre işbölümü daha hızlı ve verimlidir çünkü iş bölümü (Merrill, 1970); $>$ Öğrenme işi için harcanan zamandan kazandırır. Bir kişi tüm süreci öğrenmektense sürecin küçük bir parçasını öğrenirse çıraklık için geçireceği zamandan tasarruf edecektir.

$>$ Öğrenme sürecinde heba edilen araç gereçten tasarruf ettirir. Hatalar ve denemeler sonucu harcanacak materyal ve zarar verilecek gereçler tüm süreci öğrenmede daha fazladır.

$>$ İş arası geçişler arasındaki zaman kaybını azaltır. Bunun yanında aynı iși yapmaktan doğacak alışkanlık kas yorgunluklarını da azaltacaktır.

> Birçok sanatta ve işte araç gereç değişimi ince ayarlar ve nazik işlemler gerektirebilir. Bu da zaman ve motivasyon kaybına neden olacaktır.

$>$ Aynı işi yapmaktan dolayı bir beceri kazandırır ki işbölümünü uzmanlaşmaya götüren unsur da budur. Kazanılan beceriler sonucu kişi o işte uzman olacaktır.

$>$ Bir iş tek bir kişi tarafından yapılıyorsa o kişi tüm dikkatini ve gücünü o işe yöneltecektir. Böylece iş için kullandığı araç ve gereçte yaratacağı gelişmeler için ya da işin yapılmasında bulacağı kolay ve pratik yöntemler için zihnini daha iyi yönlendirebilecektir.

Babbage, Smith'in teorilerini almıș ve çeșitli yönlerden geliștirmiștir. İș bölümünün zihinsel operasyonlarda da kullanılabileceğini dile getirmiş, bunun içinde "School of Bridges and Roads" direktörü G.F. Prony'nin çalışanlarını vasıflı, yarı-vasıflı ve vasıfsız olarak bölerek detaylı matematiksel tablolar hazırlatması örneğini vermiştir. Bu yöntemle Prony iyi, vasıflı matematikçilere karmaşık görevleri vermiş; aradaki seviyeleri en vasıfsız gruba ise basit, angarya fakat gerekli ufak ișlemleri yaptırmıştır (Dumville ve Torano, 1997). Bu şekilde uzmanların angarya işlerle zaman harcamasını önlemiş ve zamandan tasarruf etmiştir. İş bölümünün zihinsel süreçlerde de kullanılması daha sonraları Fayol'un yönetim fonksiyonlarına ve 14 temel ilkesine ilham kaynağı olacaktır. İște işbölümü ile yönetim süreci bu noktada aynı yol üzerine girmektedir.

\section{Klasik Yönetim Düşüncesi ve İş Bölümü}

Klasik yönetim düşüncesi iki ana fikir etrafında toplanmıştır. Birincisi rutin ișlerin görülmesinde insan unsurunun makinelere ek olarak nasıl etkili bir șekilde kullanılabileceği, ikincisi de biçimsel organizasyon yapısının oluşturulmasıdır (Koçel, 2007). Klasik teorinin temelinde her zaman en fazlayı üretebilmek yatmaktadır, temel olan verimliliktir. Klasik teori insan dışındaki faktörler üzerinde durmuş ve insanı yönlendirme sonucu her işi yapabilecek bir makine olarak görmüştür ve teorinin temel hareket noktası rasyonellik olup insanın kendine söyleneni yapan ekonomik ve rasyonel düşünen bir makine olduğu varsaymıyla hareket etmektedir (Meek ve Skinner, 1973).

Klasik yönetim düşünürlerinden Taylor ve izleyenleri her zaman daha çok ve hızlı üretmek üzerinde durmuşlar, bilerek veya farkında olmadan Adam Smith ve Babbage'ın yöntemlerini takip etmişlerdir. Taylor'un dikkatini çeken en önemli husus işyerindeki verimsiz çalışma koşullarıdır, diğer bir husus ise işçilerin işlerini kendi bildikleri şekilde yapmaları ve iş usullerinin standartlaşmamış olduğudur. Bu tespitler üzerine Taylor reçetesini belirlemiş, gelişigüzel çalışma değil bilim, başıbozukluk değil ahenk ve koordinasyon, kişisellik değil yardımlaşma, düşük verim değil maksimum çıktı ve en yüksek verim için eğitimin gerekli olduğunu öne sürmüştür (Koçel, 2007). Taylor bu duruma yönelik ilk olarak işçi ve yönetim arasında iş ve sorumluluk bölümü yapılması gerektiği üzerinde durmuştur. Aslında Taylor'un "Maden Cevheri Kürekleme" deneyi Adam Smith ve Babbage'ın "iğne fabrikası" deneyinden çok farklı değildir. Taylor fikirlerini temel aldığ Smith ve Babbage gibi iş bölümlendirmesini ön planda tutmuştur. 
Her iş ve bu işi oluşturan unsurların (görevler) ayrılması gerektiği görüşü üzerinde durmuş ve tüm araştırmasını bu görüş üzerinden gerçekleştirmiştir. Bölümlenmiş her görev için zaman etütleri yapmış, gereksiz tüm faaliyetleri atıp bu bölümlendirme sürecini en etkili şekilde uygulamaya koymayı başarmıştır. Açıç̧a görüldüğü gibi Taylor'un fikirleri Smith ve Babbage'ınkinden çok farklı değildir, Taylor sadece bu fikirleri bir adım daha ileriye taşıyıp kullanılan araç gereç, standart zamanlar, standart yöntemler ile daha sistematik hale getirmiştir. Asıl olarak diğer tüm ilkeleri bu iş bölümünü en etkin biçimde çalıştırmaya yöneliktir (Applegate, 2003). Taylor yönetici kavramını da bu sebeple ortaya atmıștır, zira yönetici Taylor’a göre salt görevlendirici, emir verici ve kontrol edicidir. Taylor'un en bilinen araştırması "kömür madenleri deneyi"dir ancak Taylor'un araştırmalarının önemli bir test yeri daha bulunmaktadır; Ford otomobil fabrikası. Taylor'un ilkelerinin sıkı takipçisi olan Henry Ford, Taylor'un öngördüğü gibi işi en minik parçalarına ayırmış ve bu süreci bir üretim bandı üzerine yerleştirerek daha da hızlı ve mekanik hale getirmiştir. Fakat işleri o kadar küçük parçalara bölmüștür ki artık herhangi bir insan bile hiç bilgisi olmadan o iși yapabilecek duruma gelmiștir. Bu da işi çok sıkıcı ve monoton bir hale getirmiş, işçilerin işi bırakmasına sebep olmuş ve yenilerin de işletmeden uzak durmalarına yol açmıștır (Eren, 2008).

Henri Fayol'un görüşleri de Taylor'unkinden çok farklı değildir. Fayol "yönetsel teoriyi" ve yönetimin fonksiyonlarını ortaya koyarken Taylor'un birbirinden ayrı tuttuğu yönetici ile işçi gruplarından daha çok yöneticilerin üzerinde yoğunlaşmıștır. Fayol yöneticinin sistemi yönetmesi gerektiğini savunarak organizasyonel faaliyetleri 6 ana gruba ayırmıştır. Aslında bu ayırma işi fonksiyon temelli iş bölümlendirilmesinden bașka bir şey değildir. Keza bu 6 fonksiyonu da Tablo 1 de görülen, 14 ilke ile desteklemektedir. Fakat 14 ilkenin ilkinin "iş bölümü" ilkesi olması dikkat çekicidir. Fayol'a göre işbölümü doğada mevcuttur, bu nedenle iş bölümü doğal bir kuraldır. Öte yandan Fayol iş bölümünün örgütlerin temel özelliklerinden birini teşkil ettiğini ve örgütün büyüklüğünün bir türevi olduğunu ifade etmiştir (Baransel, 1993). Fayol'a göre işbölümü verimliliği artırmakta olup bunun başlıca nedeni de uzmanlaşmaya yol açmasıdır. İş bölümü teknik ve icra ișlerde olduğu gibi yönetsel faaliyetlerde de uzmanlaşmaya ve görev bölünmelerine olanak sağlamaktadır. Fayol burada ikinci "Fayol köprüsünü" kurmaktadır. Üzerinde durulması gereken asıl köprü belki de budur. Aslında bu bakış açısıyla Fayol burada Babbage'in işbölümünün sadece teknik işlerde değil zihinsel süreçlerde de etkili olduğu görüşünü desteklemektedir. Fayol, Taylor ile birlikte ortaya koyduğu "yönetici" kavramını da işbölümü ile harmanlayarak "klasik organizasyon" teorisine bağlamaktadır. Bugün de organizasyon ilkelerinin temeli olan bölümlere ayırma ilkesinin çıkış noktası tamamen budur (Baransel, 1993). İş bölümü hariç diğer 13 ilke incelendiğinde bu yönetsel işbölümünün yapısı, süreci ve sonuçlarına ilişkin çıkarımlar elde edilecektir. Yeni bir yaklaşım olarak; yönetsel işbölümü, işbölümünün yapısı ile ilgili ilkeler, yönetsel işbölümünün süreci ile ilgili ilkeler, yönetsel işbölümünün sonuçları ile ilgili ilkeler şeklinde bir sınıflandırma yapıldığında daha bahsi geçen bakış açılarına daha uygun olacağı düşünülmektedir.

\begin{tabular}{|l|l|l|}
\hline \multicolumn{2}{|c|}{ Yönetsel İş Bölümü } \\
\hline Yapıssal ilkeler: & Süreç ilkeleri: & Sonuçlarla ilgili ilkeler: \\
* Yönetim Birliği & * Kumanda birliği & * Düzen \\
* Merkezcilik & * Disiplin & * Devamlılık \\
* Hiyerarş̧i & * Adalet & * Birliyatik ve beraberlik \\
& * Maaş ve ücretler & \\
& * Genel çlkarların kişisel çıkarlara & \\
& üstünlüğü & \\
\hline
\end{tabular}

Tablo 1: Fayol'un 14 ilkesinin sınıflandırılması 
Yönetimde işbölümü ilkesini yapısal ilkeler arasına koymak tüm diğer ilkelerin sebebi olan bu ilkeye bir sınıflandırma hatası yapmak olacaktır. Açıcça görüldügü gibi herhangi bir işbölümü olmadığında bu işbölümünü sürdürecek diğer 13 ilkeye de gerek kalmayacaktır. Bölümlendirilmemiş bir yapıda hiyerarşi veya merkeziyetçilikten bahsetmek anlamsız bir uğraștır. Bunların yanında Fayol, teknik ișlerde Taylor'un savunduğu işbölümü ve uzmanlaşmanın da sıkı bir taraftarı durumundadır. Bununla birlikte halen insanı bir makine olarak görme fikrinden uzak değildir. Fayol'un fikirleri de eklendiğinde, işbölümünü teknik ve yönetsel kademede olmak üzere iki farklı yönden incelemek gerekmektedir. Yönetsel kademedeki işbölümüne yönelik yapılan eleștiriler daha çok iyileştirmeye yönelik olsa da teknik işbölümü ve uzmanlaşma üzerine yıllardır tartışmalar yapılmakta, çok farklı görüşler ortaya atılmaktadır (Baykal, 1981). Weber de ortaya koyduğu bürokrasi yaklaşımıyla Taylor ve Fayol gibi uzmanlaşmayı savunmaktadır. Bu yaklaşımın temel unsurları fonksiyonel uzmanlaşmaya dayalı, ileri derecede işbölümü, işbölümü sonucu çeșitli parçalara ayrılan işlerin koordinasyonu için otoritenin merkezileșmesi ve hiyerarşik bir yapıya bürünmesidir (Weber, 2004). Bu doğrultuda bürokratik idari yapının özellikleri düzenli işbölümü, hiyerarşi, kurallar, resmiyet, liyakat esasına göre istihdam, kariyer olarak memuriyet biçiminde özetlenmiștir (Leblebici, 2008).

Bahsi geçen görüşlere belki de en yakın görüşü Luther Gulick dile getirmiștir. Gulick'e göre, belirli sayıda insan birlikte çalışıyorsa en iyi sonuç, bu kimseler arasında işbölümü yapıldığı takdirde elde edilir (Edmund, 1972). Luther Gulick işbölümünün örgütün temel unsurunu ve nedenini teșkil ettiğini ileri sürmektedir (Baransel, 1993). İş bölümünün nedenini de insanoğlunun öğrenme, kapasite, kabiliyet olarak sınırlı düzeyde olmasına bağlamış ve insanların sonsuz bilgi havuzundan sadece küçük bir bölümünü öğrenebileceğini belirtmiştir. Dolayısıyla işbölümünün, çeşitli yeteneklerden daha iyi yararlanmayı mümkün kılacağını, zamandan tasarruf sağlayacağını ve uzmanlaşmanın kendine has getirileri olacağını ifade etmiștir (Gulick, 1937; Shell, 2002). İș bölümünün gerekliliğini, çalıșanların yeteneklerinin ve kapasitelerinin farklı olmasına, her șeyi bilmelerine imkân olmadığına ve bir çalışanın aynı anda iki işi birden yapmasının zorluğuna dayandırmıștır. İș bölümü sayesinde zamanın etkili kullanılabileceği, çalışanların yeteneklerinden en iyi biçimde faydalanılabileceği ve kaynakların da daha etkili kullanılabileceği iddia edilmiştir (Leblebici, 2008). Kısacası işbölümünün koordinasyonunun sağlanması gerektiğini bunun da ancak yapısal, süreç odaklı ve örgütsel ilkelerin uygulanmasıyla olabileceğini vurgulamıştır (Shell, 2002).

Görüldüğü gibi işbölümü ve uzmanlaşma sadece klasiklerin kullandığı bir yapı değildir. İș bölümü toplum yașamı kadar eski bir kavramdır. Milattan önce antik çağlardan günümüze kadar evrimleşen bu süreç klasik teoride artık yönetsel işbölümünü de yanına alarak hem teknik hem de yönetsel işbölümü olarak karşımıza çıkmaktadır. Çalıșmada bahsedilen kişiler ve bahsedilmeyen birçok kişi işbölümü üzerinde durmuştur. Kimi teknik (Adam Smith), kimi toplumsal (Durkheim), kimi yönetsel (Fayol), kimi de zihinsel ve teknik (Babbage) anlamda ișbölümü üzerinde durmuștur, fakat hepsinin dile getirdiği ortak nokta işbölümünün maliyetleri düşürücü, zamandan kazandırıcı ve verimliliği artırıcı bir olgu olduğudur (Vincent, 2004).

Tüm bu görüşler insan unsurunun ve insan ilişkilerinin ele alındığg ve önemsendiği "Neoklasik Yaklaşım”a kadar devam etmiștir. Ancak bu yaklașımın öncüleri işbölümünün iş tatminini azaltıcı etkilerini göz önüne almışlar, ileri derecede işbölümünün işi monoton ve anlamsız hale getirdiğini ve çalışanı psikolojik bakımdan olumsuz etkilediğini dile getirmişlerdir. Neoklasik yaklaşım ile çok küçük parçalara bölünen işin genişletilmesi ve işçilerin farklı farklı işlerde çalıştırılmasıyla iş monotonluğunun azaltılması önerilmiştir (Koçel, 2007). Neoklasik yaklaşım bu tip 
önerilerde bulunmuş olduğu halde 2. dünya savaşı sırasında ileri derecede işbölümüne ihtiyaç duyulmuştur. Hatta Taylorizme karşı olan Japonya'da bile iki farklı görüş ortaya çıkmıştır. Bunlardan biri eğitim yoluyla marifetli ustalar yetiştirip, üretimi hızlandırmak, diğeri ise tüm işi gücü bırakıp iş bölümlendirmesi yardımıyla üretilebilecek maksimum sayıda silahı üretmek șeklinde olmuștur (Cranier, 1999).

\section{Sonuç}

İnsanlık tarihi kadar eski olan işbölümü kendi içerisinde evrimleşmiş ve şekillenmiştir. Bugüne kadar işbölümü hakkında birçok olumlu ve olumsuz eleştiride bulunulmuştur. Ancak görüş birliğine varılan husus iş bölümünün üretimi artırdığı fakat iş tatminini düşürdüğüdür. İş bölümü ile yönetim düşüncesinin evrimini birbirinden ayırmak imkânsız gibidir. Günümüzde iş bölümü yönetim, insan kaynakları ve örgütsel davranış gibi birçok bilimsel alanda kendine yer bulmuş ve inceleme konusu olmuştur. Bu çalışmada yüzyıllar önce ortaya çıkan iş bölümünün klasik örgüt yapısına kadar nasıl şekillendiği ortaya konmakta olup aynı zamanda klasik yönetim düşüncesiyle birlikte tanımlanan işbölümü kavramı "yönetsel ișbölümü" adı altında irdelenmektedir. Elbette klasik yönetim anlayışıyla çıkan yapı da halen değişmekte ve evrimleşmektedir, önemli olan işbölümünü zihinsel ve teknik işlerde farklı düşünmek ve yorumlamaktır. Yönetim biliminin çıkış noktasını araştırırken bu bilgiler ihmal edilemez gerçekler olarak karşımıza çıkacaktır. Elbette ki tartışmalar ve şekillenmeler yıllarca devam edecek ve işbölümü kavramı yeni şekiller alacaktır. Bu doğrultuda gerçekleştirilecek olan yeni çalışmalar işbölümü ve uzmanlaşmanın günümüze kadar uzanan evrimini ele alarak daha geniş bir bakıș açısı sağlayacaktır.

\section{KAYNAKÇA}

APPLEGATE, E. (2003). Business: the ultimate resource. Journalism and Mass Communication Quarterly, Cilt 80(2), 451.

BABBAGE, C. (1832). On the economy of machinery and manufactures... enlarged. Charles Knight, Londra.

BARANSEL, A. (1993). Çağdaş yönetim düşüncesinin evrimi. İstanbul Üniversitesi İşletme Fakültesi Yayınları. Avcıol Basın Yayın.

BAYKAL, B. (1981). Organizasyonların yönetimi: ilkeler ve süreçler. Met/Er Matbaasi.

CHANDRA, R. (2004). Adam Smith, Allyn Young, and the division of labor. Journal of Economic Issues, Cilt 38(3), 787-805.

CHENG, W., \& YANG, X. (2004). Inframarginal analysis of division of labor: a survey. Journal of Economic Behavior \& Organization, Cilt 55(2), 137-174.

CRAINER, S. (1999). The 75 greatest management decisions ever made. The Journal for Quality and Participation, Cilt 22(6), 46.

DUMVILLE, J. C., \& TORANO, F. A. (1997). Division of labor, efficient? Empirical evidence to support the argument. SAM Advanced Management Journal, Cilt 62(2), 16.

EREN, E. (2008). Yönetim ve organizasyon. Beta Yayınları

GREINER, L.E. (1972). Evolution and revolution as organizations grow. Harvard Business Review, Cilt 50(4), 37-46.

Theory, 3.

GULICK, L. (1937). Notes on the theory of organization. Classics of Organization

HODGETTS, R. M. (1997). Yönetim: teori, süreç ve uygulama. Çev. Çetin, C. Mutlu, E. Der Yayınları. 
KOÇEL, T. (2007). İșletme yöneticiliği (yönetim ve organizasyon,

organizasyonlarda davranıș, klasik-modern-çağdaş ve güncel yaklaşımlar). Beta Yayınları

LEBLEBİCİ, D. N. (2008). Yönetim bilimi açısından klasik dönemi hatırlamaya

ilișkin bir çalıșma. Dumlupınar Üniversitesi Sosyal Bilimler Dergisi, 21, 99-118.

MEEK, R. L., \& SKINNER, A. S. (1973). The development of Adam Smith's ideas on the division of labour. The Economic Journal, Cilt 83(332), 1094-1116.

MERRILLL, H.F. (1970). Classics in Management. American Management Association.

NARIN, Ö. (2010). Techonology and the division of labour in Smith and Marx: A comparative analysis. Politik Iktisat ve Adam Smith, Proceedings of the International Conference on Political Economy (ICOPEC).

NiŞANCI, Z.N. (2015). Geçmişten Günümüze Yönetim Düşüncesi. Yönetim Bilimleri Dergisi, 13(25), 257-294.

PAVITT, K. (1998). Technologies, products and organization in the innovating firm: what Adam Smith tells us and Joseph Schumpeter doesn't. Industrial and Corporate change, Cilt 7(3), 433-452.

ROSENBERG, N. (1965). Adam Smith on the division of labour: two views or one?. Economica, Cilt 32(126), 127-139.

SHELL, R. (2002). Management of professionals, revised and expanded. CRC Press.

SMITH, A. (2005). From the Wealth of Nations. In Readings in The Economics of The Division of Labor: The Classical Tradition, 93-123.

VINCENT, L.S. (2004). The division of labour: Is there a difference between organisation and the market. Cambridge Journal of Economics. İstanbul.

WEBER, M. (2004). Sosyoloji yazıları, Çev. Taha Parla, İletișim Yayınları, 6. Baskı,

WEST, A. (1999). The flute factory: an empirical measurement of the effect of the division of labor on productivity and production cost. The American Economist, 43(1), 82-87.

WREN, D.A. (1972). The evolution of management thought. The Ronald Press Company.

ZAGOLOV, N. (1976). Ekonomi politiğin temelleri. May Yayınları, İstanbul

ZAN, L. (2004). Accounting and management discourse in proto-industrial settings: the Venice Arsenal in the turn of the 16th century. Accounting and Business Research, 34(2), 145-175.

\section{Summary}

The concepts of management and organization have been changed throughout the known history of humankind. Management and organization concepts are an ongoing concept since the beginning of humankind. All civilizations have benefited from the organization process and management while putting forth their works. The earliest examples of the division of labor in history are found in Sumerians. China's wars with Central Asian Turks have also caused them to keep military organization very tight. In the work entitled "Art of War" written by Sun Tzu in 500 B.C., the vital importance of specialization and division of labor has been emphasized from a military perspective, and it has also been emphasized that a military structure should be consisted of very small parts of labor divided by definite lines and that the soldiers assigned in every division should only do their own work. In the civilization established by the Romans, semi-factory production systems that produce weapons for the Roman legions, which put more emphasis on the military structure, have been developed and then the same system has also been used for the textile they 
produce for commercial purposes.

Adam Smith's "needle factory" research has started to be discussed after the theory of division of labor. Smith has examined the division of labor, which is the basic source of effectiveness, on three bases; the skills of the worker, the time gained as a result of the absence of switching from task to task, better techniques, machines and creativity.

About 50 years after Smith, Charles Babbage added a fourth factor to this effectiveness, referring to Smith's early debates: cost reduction. Although Smith addressed this issue by stating that productivity can be increased by increasing the performance of the workforce, Babbage calculated how the division of labor would reduce labor costs and increase profitability. Babbage has taken Smith's work a step further, by taking into account the cost and profitability through economy from skill and labor force, in addition to improving output. As an English mathematician, the works of Babbage have led him to surprising results that are compatible with management. Babbage's research in the factories led him to Smith's path, deepening Smith's needle factory research and bringing him to principles that lead to major changes later on. Taylor and his followers have always focused on producing more and faster, following the methods of Adam Smith and Babbage intentionally or unwittingly. The most important issue that attracts Taylor's attention was the inefficient working conditions at work, another point was that the workers do their work in their own way, without any standardized work procedures. The views of Henri Fayol are not very different from Taylor's. While Fayol has put forth the "managerial theory" and the functions of management. Fayol has divided the organizational activities into six main groups, arguing that the manager should only manage the system. This point of view is now addressed in terms of both technical and managerial division of labor in classical theory. The scholars mentioned in the study and many others who were not mentioned have focused on the division of labor.

Classifying the managerial division of labor principle under the "structural principles" is a classification error since this principle is the cause of all other principles. The division of labor, which is as old as human history, has evolved and shaped in time. There have been many positive and negative criticisms about the division of labor so far. However, the consensus is that the division of labor increases production, but decreases job satisfaction. It is almost impossible to distinguish between the evolution of division of labor and the evolution of management concept. Today, the division of labor has found its place in many scientific fields such as management, human resources and organizational behavior. This study addresses the transformation of the division of labor that emerged centuries ago into the classical organizational structure. Of course, the structure of classical management approach is also changing and evolving, but what is important here is to interpret the division of labor differently in cognitive and technical works. When investigating the starting point of management science, this information will emerge as non-negligible facts. Of course, discussions and its evolution will continue for years, and the concept of division of labor will take new forms. The new studies to be conducted in this direction will provide a broader perspective by addressing the evolution of the specialization and division of labor up to the present day. 